\author{
Agnieszka Sompolska-Rzechuła \\ West Pomeranian University of Technology in Szczecin \\ e-mail: agnieszka.sompolska-rzechula@zut.edu.pl \\ ORCID: 0000-0002-0647-1570
}

\title{
SELECTION OF THE METHOD OF LINEAR ORDERING USING THE EXAMPLE OF ASSESSING THE LEVEL OF SOCIO-ECONOMIC DEVELOPMENT OF EUROPEAN UNION COUNTRIES
}

DOI: $10.15611 /$ pn.2020.7.09

JEL Classification: C39, Q01

(C) 2020 Agnieszka Sompolska-Rzechuła

This work is licensed under the Creative Commons Attribution-ShareAlike 4.0 International License. To view a copy of this license, visit http://creativecommons.org/licenses/by-sa/4.0/

Quote as: Sompolska-Rzechuła, A. (2020). Selection of the method of linear ordering using the example of assessing the level of socio-economic development of European Union countries. Prace Naukowe Uniwersytetu Ekonomicznego we Wrocławiu, 64(7).

\begin{abstract}
The aim of the article is to present the issues of choosing the optimal procedure for the linear ordering of objects and assessing the correctness of the selected methods of the linear ordering. The goal was achieved by creating linear ordering of objects using various methods for normalizing the value of diagnostic features. An aggregate measure based on various properties of the synthetic feature was used to select the optimal ordering, among others, the compatibility of the mapping, the correlation of the synthetic line variable with diagnostic variables, the rank correlation of the synthetic variable with diagnostic variables and the variability of the synthetic variable. The study was conducted based on the example of data concerning 28 European Union countries according to the level of socio-economic development in the context of sustainable development concerning society, economy and the environment. The linear ordering of countries using the quotient transformation with an arithmetic mean turned out to be the most correct ordering.
\end{abstract}

Keywords: linear ordering, optimal method, normalization of diagnostic features.

\section{Introduction}

There are many proposals for the construction of synthetic features in the literature on the subject. The first proposal of a synthetic measure was presented by Hellwig (1968) and it allowed linear ordering of objects using a pattern. Hellwig's proposal 
became an inspiration for further research in the field of linear ordering methods, which resulted in both modifications of the economic development measure and new original proposals for the construction of synthetic variables (Bąk, 2013). Linear ordering methods are used to evaluate multi-feature objects, enabling them to be ranked, according to a specific general criterion, from 'best' to 'worst'. This criterion is treated as a property of the examined objects and is a complex phenomenon that is not subject to direct measurement. To determine it, sets of diagnostic features are used, measured on various measuring scales.

The methods used to build the synthetic feature differ from each other, among others the way of normalizing the value of diagnostic features, which leads to depriving the physical units of the measurement results and unifying the orders of magnitude of the feature. The literature contains many proposals for these methods and discussions on the criteria for their selection. Normalizing methods can be divided into (Kukuła, 2000): methods based on quotient transformation and rank methods. In the first group of methods, various reference points are used, e.g. standard deviation, range, arithmetic mean, maximum or minimum value of the feature. Normalization procedures using the indicated reference points meet the demands of normative formulas to varying degrees. Kukuła (2000) indicates seven postulates: removing titers, reducing the order of magnitude of diagnostic features for comparability, equality of the length of ranges of variability of values of all normalized features, the possibility of normalizing diagnostic features taking both positive and negative values and the value equal to zero, non-negativity of normalized values and the existence of simple formulas unifying the nature of the features.

Frequently, several methods using selected standardization procedures are used to study various phenomena. Then the question arises as to the results of which ordering should be considered final and optimal? The correctness of synthetic features, which are based on various properties of the synthetic feature, may be helpful in obtaining and answer to this question. The quality assessment of linear ordering procedures is the last step in creating a synthetic variable. In the literature on the subject, one can find mainly works whose final result is to organize objects without assessing the correctness of the obtained results.

The aim of the article is to present the problems of choosing the optimal procedure for the linear ordering of objects and to assess the correctness of selected methods of the linear ordering of objects. This goal was achieved through:

- creating linear ordering of European Union countries using selected standardization methods,

- selection of the optimal ordering of countries.

The selection of the optimal procedure for the linear ordering of EU countries is illustrated by the example of the level of socio-economic development, which was presented using indicators reflecting the concept of sustainable development and is implemented in three dimensions: economic, social and ecological. It is based on the pursuit of the best economic result while respecting the natural environment 
and social development. Therefore, it is such a social and economic development that ensures that the needs of modern society are met without hindering future generations from meeting their needs.

\section{Research method}

The aim of the study was achieved as a result of building a linear ordering of European Union countries using a method based on the synthetic feature. The synthetic feature creation procedure is a multi-step process and includes (Wysocki, 2010):

- selection of simple features - important from the point of view of the studied phenomenon, measuring them for the tested objects and preparing a final list of features by removing features with low variability and features overly correlated with others;

- determining the direction of preferences of simple features in relations to the general criterion under consideration and normalizing them;

- choosing the appropriate aggregation method and determining the value of a synthetic development measure for each object;

- construction of the object ranking;

- recognition of developmental types, substantive assessment and interpretation of obtained results;

- quality assessment of rankings using partial quality assessment criteria and aggregate measures were calculated.

The basis of linear ordering is a synthetic feature whose values are estimated based on observations of diagnostic variables describing the examined objects. The synthetic feature is a latent variable because its realizations are not directly observed. However, diagnostic features are directly measurable (Bąk, 2015). Two groups of methods can be distinguished that are used to determine the value of a synthetic feature: non-reference methods and reference methods.

Due to the purpose of the study, in this paper the authors determine the synthetic feature, the proposition was to use different standardization methods and to assess the quality of the obtained orders.

The following standardization methods from the group of methods based on the quotient transformation were used in the study (Kukuła, 2000):

$$
\begin{gathered}
z_{i j}=\frac{x_{i j}-\bar{x}_{j}}{s\left(x_{j}\right)} \quad s\left(x_{j}\right)>0 \\
z_{i j}=\frac{x_{i j}}{s\left(x_{j}\right)} \quad s\left(x_{j}\right)>0 \\
z_{i j}=\frac{x_{i j}}{\max _{i} x_{i j}-\min _{i} x_{i j}} \quad \max _{i} x_{i j} \neq \min _{i} x_{i j}
\end{gathered}
$$




$$
\begin{array}{cc}
z_{i j}=\frac{x_{i j}-\bar{x}_{j}}{\max _{l} x_{l j}-\min _{l} x_{l j}} & \max _{i} x_{i j} \neq \min _{i} x_{i j} \\
z_{i j}=\frac{x_{i j}-\min _{l} x_{l j}}{\max _{l} x_{l j}-\min _{l} x_{l j}} & \max _{i} x_{i j} \neq \min _{i} x_{i j} \\
z_{i j}=\frac{x_{i j}}{\max _{l} x_{l j}} & \max _{i} x_{i j} \neq 0 \\
z_{i j}=\frac{x_{i j}}{\min _{l} x_{l j}} & \min _{i} x_{i j} \neq 0 \\
z_{i j}=\frac{x_{i j}}{\bar{x}_{j}} & \bar{x}_{j} \neq 0 \\
z_{i j}=\frac{x_{i j}}{\left(\sum_{i=1}^{m} x_{i j}^{2}\right)^{\frac{1}{2}}} & \sum_{i=1}^{m} x_{i j}>0
\end{array}
$$

The formulas (1) to (9) adopted the following symbols:

- $x_{i j}(i=1,2, \ldots, n ; j=1,2, \ldots, m)$ - values of diagnostic features,

- $n$-number of objects,

- $m$ - number of features,

- $\bar{x}_{j}$ - arithmetic mean of the value of the feature $X_{j}$,

- $s\left(x_{j}\right)$ - standard deviation of the feature $X_{j}$,

- $\max _{i} x_{i j}, \min _{i} x_{i j}-$ maximum and minimum value of the feature $X_{j}$,

- $z_{i j}$ - normalized value of the feature $X_{j}$.

- Based on the values of the normalized diagnostic features according to the transformations (1) to (9), the synthetic feature values were determined using the reference method based on averaging the values of the features:

$$
\mu_{i}=\frac{1}{m} \sum_{j=1}^{m} z_{i j}
$$

where: $\mu_{i}$ - value of the synthetic feature for the $i$-th object.

When several methods of building linear ordering of objects are used in research, the question arises as to the results of which ordering should be considered final and optimal at the same times? What might be helpful in getting the answer to this question might be the measures of correctness of synthetic variables, which are based on various properties of the synthetic feature. The quality assessment of linear ordering procedures is the last step in creating a synthetic variable. In the literature on this subject, one can find mainly works in which final result is a ranking of objects without assessing the correctness of the obtained results. This paper proposed the use 
of partial criteria for ordering quality assessment and an aggregate measure (Bąk, 2015, 2018).

The final stage in the construction of the synthetic variable is the assessment of the correctness of the procedure of the linear ordering of objects. To this end, measures are used to characterize the effectiveness of individual methods for determining synthetic variables. These measures can be divided into five groups, each of which includes measures related to different properties of synthetic variables (Grabiński, Wydymus, and Zeliaś, 1989): mapping compatibility $\left(m_{1}-m_{3}\right)$, linear correlation of the synthetic variable with diagnostic variables $\left(m_{4}-m_{5}\right)$, rank correlation of the synthetic variable with diagnostic variables $\left(m_{6}-m_{8}\right)$, variability and concentration of the synthetic variable $\left(m_{9}-m_{10}\right)$, and taxonomic distance of the synthetic variable from the original variable $\left(m_{11}-m_{12}\right)$.

The following measures from individual groups were used in this study:

$$
m_{1}=\frac{\sum_{i=1}^{n-1} \sum_{j>i}^{n}\left(d_{i j}-\tilde{d}_{i j}\right)^{2}}{\sum_{i=1}^{n-1} \sum_{j>i}^{n} d_{i j}^{2}}
$$

where: $d_{i j}$ - distance between the $i$-th and $j$-th object in the one-dimensional space of the synthetic variable, $\tilde{d}_{i j}$ - distance between the $i$-th and $j$-th object in the $m$-dimensional space of standardized diagnostic variables, $n$ - number of objects,

$$
m_{4}=1-\frac{1}{m} \sum_{j=1}^{m} r_{q x_{j}}
$$

where: $r_{q x j}$-correlation coefficient between the $j$-th diagnostic variable and synthetic variable,

$$
m_{6}=1-\frac{1}{m} \sum_{j=1}^{m} \rho_{q x_{j}}
$$

where: $\rho_{q x j}$ - Spearman's rank correlation coefficient between the $j$-th diagnostic variable and the synthetic variable,

$$
m_{9}=-\frac{s_{\mu}}{\bar{\mu}}
$$

where: $\bar{\mu}$ and $s_{\mu}$ - mean and standard deviation of the synthetic variable.

Based on the analysis of the correlation coefficients between individual measures, it was determined that they have the same direction of preferences. The lower the values of individual measures, the 'better' the synthetic variable. Therefore, one can aggregate these measures according to (Bąk, 2015):

$$
M_{q}=\sqrt{\sum_{l=1}^{g} g_{l}^{2}}
$$


where: $M_{q}$ - aggregate measure of the $k$-th configuration of elements of the linear ordering procedure, $g_{l}$ - partial measure $(l=1, \ldots, g), g$ - number of partial measures.

\section{Research material}

To achieve this goal, data on 28 EU Member States were used. The information concerned 2015 and 2016 (Eurostat, 2017). The selection of features was guided by the characteristics provided by Eurostat concerning society, economy and the environment. The initial list of diagnostic features regarding the socio-economic situation of countries was as follows:

$X_{1}$ - live births per 1000 population,

$X_{2}$ - deaths per 1000 population,

$X_{3}$ - infant deaths rate per 1000 population,

$X_{4}$ - natural increase per 1000 population,

$X_{5}$ - age dependency (population aged 0-14 and 65 and more per 100 persons aged 15-64),

$X_{6}$ - activity rate in $\%$,

$X_{7}$ - employment rate in $\%$,

$X_{8}$ - unemployment rate in $\%$,

$X_{9}$ - at-risk-of poverty rate in $\%$,

$X_{10}$ - severely materially deprived people in \%,

$X_{11}$ - GDP per capita in thousand euro,

$X_{12}$ - investment rate in $\%$,

$X_{13}$ - industrial production $(2015=100)$,

$X_{14}$ - obtaining primary energy per 1000 inhabitants from renewable energy sources (in thousand tone),

$X_{15}$ - final energy consumption per capita (in thousand kgoe),

$X_{16}$ - share of high-tech exports in total exports in \%,

$X_{17}-$ net current account balance in $\%$ of GDP.

One of the most important problems in economic research conducted using multidimensional methods of data analysis (including methods of linear ordering) is the selection of features. This involves the elimination of those features from the set that are characterized by low variability and are strongly associated with other features.

In the subject literature, one can find many methods used in the selection of features. These include the following procedures: a method based on the analysis of correlation coefficients between features (parametric Hellwig method, inverted correlation coefficient matrix method), factor analysis or classification methods applied to the feature space (Bąk, 2017). One of these methods is the procedure proposed by Hellwig and known as the parametric method of feature selection. A detailed description of this method can be found, for example, in (Bąk, 2017; 
Hellwig, 1968; Sompolska-Rzechuła, 2018; Wysocki, 2010). In this work, this method was used to eliminate features strongly correlated with others and the final set of diagnostic features was obtained, taking into account:

$X_{8}$ - unemployment rate in \%,

$X_{10}-$ severely materially deprived people in $\%$,

$X_{12}$ - investment rate in $\%$,

$X_{14}$ - total production of primary energy per capita (in thous. kgoe),

$X_{16}$ - share of high-tech exports in total exports in \%,

$X_{17}$ - net current account balance in \% of GDP.

Table 1 presents the values of the basic descriptive parameters of the features finally adopted for the study.

Table 1. Descriptive statistics of variables

\begin{tabular}{|l|c|c|c|c|c|c|}
\hline \multirow{2}{*}{\multicolumn{1}{|c|}{ Statistics }} & \multicolumn{7}{c|}{ Variables } \\
\cline { 2 - 7 } & $X_{8}$ & $X_{10}$ & $X_{12}$ & $X_{14}$ & $X_{16}$ & $X_{17}$ \\
\hline Mean & 8.65 & 8.93 & 20.01 & 49.75 & 12.26 & 2.16 \\
\hline Minimum & 4 & 0.7 & 11.4 & 13.33 & 3.8 & -5.3 \\
\hline Maximum & 23.6 & 31.9 & 29.3 & 116.44 & 24.2 & 8.4 \\
\hline Skewness coefficient & 1.94 & 1.56 & 0.19 & 1.04 & 0.46 & 0.07 \\
\hline Median & 7.7 & 5.65 & 19.85 & 38.68 & 10.5 & 1.85 \\
\hline Standard deviation & 4.48 & 7.44 & 3.45 & 30.54 & 6.18 & 3.74 \\
\hline Variation coefficient & 51.82 & 83.35 & 17.22 & 77.75 & 50.43 & 172.76 \\
\hline
\end{tabular}

Source: own elaboration based on (Eurostat, 2017).

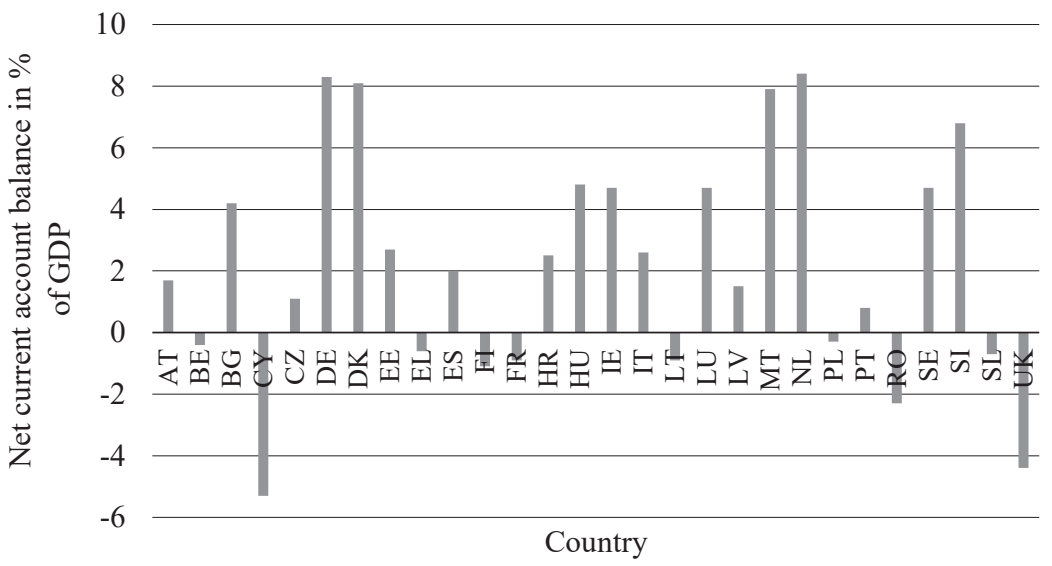

Fig. 1. Net current account balance in \% of GDP in individual countries

Source: own elaboration based on (Eurostat, 2017). 
The countries are characterized by strong or very strong variability due to all the studied features. In addition, $X_{8}, X_{10}$ and $X_{14}$ have a strong right-sided asymmetry demonstrating the advantage of counties dominated by the values of features (unemployment rate, deeper material deprivation rate and obtaining primary energy per capita) higher than the average. The strongest variability refers to the $X_{17}$ feature - net current account balance in \% of GDP. The evolution of the net current account balance in \% of GDP in individual countries is shown in Figure 1.

Some countries (Belgium, Finland, Lithuania, Poland and the United Kingdom) are characterized by a negative value of the indicator, which means that the deficit of cash turnover means that some of the goods were purchased on credit. The majority of countries had a positive current account balance, i.e. a current account surplus.

In the assessment of poverty, the indicator of in-depth material deprivation is used, which is included in this study, defined as the percentage of persons in households declaring inability to satisfy, for financial reasons, at least four out of nine needs listed below (Eurostat, 2017):

1) paying for the week-long trip of all household members to rest once a year,

2) eating meat, fish (or vegetarian equivalent) every other day,

3) heating the apartment as needed,

4) coverage of unexpected expenditure (in the amount corresponding to the monthly value of the relative poverty line adopted in the given country in the year preceding the survey),

5) timely payment of fees related to the apartment, repayment of instalments and loans,

6) owning a colour TV set,

7) owning a car,

8) owning a washing machine,

9) owning a telephone (landline or mobile).

In 2016, the indicator of in-depth material deprivation in the EU countries was marked by strong right-sided asymmetry. Countries such as Luxembourg, Finland, Denmark, Germany, the Czech Republic, and Estonia were characterized by a value below this median (5.65\%). In contrast, in Bulgaria, Romania and Greece, the value of this indicator of in-depth material deprivation significantly exceeded $5.65 \%$.

Based on the obtained set of diagnostic features, which consists of six indicators relating to society, economy and the environment, the linear ordering of EU countries was created and the best ordering from the point of view of the criteria used was selected.

\section{Results}

Six indicators were used to build a linear ordering of EU countries, two of which were considered destimulants: $X_{8}$ - unemployment rate in \% and $X_{10}$ - severely materially deprived people in $\%$. They were transformed into stimulants by means of a transformation consisting in determining the inverse value. 
Table 2 presents the results of the linear ordering of EU countries by the socio-economic situation in 2016.

Table 2. The results of the linear ordering of EU countries by the socio-economic situation in 2016 according to normative formulas (1) to (9)

\begin{tabular}{|c|c|c|c|c|c|c|c|c|c|}
\hline \multirow{2}{*}{ Country } & \multicolumn{9}{|c|}{ The method based on the standardizing formula } \\
\hline & $(1)$ & $(2)$ & (3) & (4) & $(5)$ & $(6)$ & (7) & $(8)$ & (9) \\
\hline Austria (AT) & 5 & 5 & 5 & 5 & 5 & 6 & 4 & 7 & 3 \\
\hline Belgium (BE) & 10 & 10 & 10 & 10 & 10 & 13 & 11 & 13 & 6 \\
\hline Bulgaria (BG) & 23 & 23 & 23 & 23 & 23 & 17 & 27 & 16 & 23 \\
\hline Croatia (HR) & 22 & 22 & 22 & 22 & 22 & 19 & 26 & 18 & 17 \\
\hline Cyprus (CY) & 27 & 27 & 27 & 27 & 27 & 27 & 21 & 28 & 27 \\
\hline Czech Republic (CZ) & 6 & 6 & 6 & 6 & 6 & 9 & 8 & 10 & 9 \\
\hline Denmark (DK) & 8 & 8 & 8 & 8 & 8 & 5 & 10 & 5 & 5 \\
\hline Estonia (EE) & 11 & 11 & 12 & 12 & 12 & 12 & 13 & 12 & 15 \\
\hline Finland (FI) & 16 & 16 & 17 & 17 & 17 & 21 & 7 & 17 & 22 \\
\hline France (FR) & 13 & 13 & 13 & 13 & 13 & 14 & 12 & 15 & 14 \\
\hline Germany (DE) & 3 & 3 & 1 & 1 & 1 & 2 & 5 & 3 & 2 \\
\hline Greece (EL) & 28 & 28 & 28 & 28 & 28 & 28 & 28 & 27 & 28 \\
\hline Hungary (HU) & 12 & 12 & 11 & 11 & 11 & 10 & 17 & 11 & 13 \\
\hline Ireland (IE) & 7 & 7 & 7 & 7 & 7 & 8 & 14 & 9 & 10 \\
\hline Italy (IT) & 18 & 18 & 16 & 16 & 16 & 15 & 18 & 14 & 11 \\
\hline Latvia (LV) & 20 & 20 & 20 & 20 & 20 & 18 & 23 & 19 & 18 \\
\hline Lithuania (LT) & 25 & 25 & 25 & 25 & 25 & 26 & 25 & 25 & 26 \\
\hline Luxembourg (LU) & 9 & 9 & 9 & 9 & 9 & 7 & 3 & 6 & 8 \\
\hline Malta (MT) & 2 & 2 & 3 & 3 & 3 & 3 & 6 & 4 & 4 \\
\hline Netherlands (NL) & 4 & 4 & 2 & 2 & 2 & 1 & 2 & 2 & 1 \\
\hline Poland (PL) & 19 & 19 & 18 & 18 & 18 & 20 & 16 & 22 & 24 \\
\hline Portugal (PT) & 26 & 26 & 26 & 26 & 26 & 24 & 20 & 21 & 16 \\
\hline Romania (RO) & 17 & 17 & 19 & 19 & 19 & 25 & 24 & 26 & 25 \\
\hline Slovakia (SK) & 21 & 21 & 21 & 21 & 21 & 22 & 19 & 24 & 21 \\
\hline Slovenia (SI) & 15 & 15 & 15 & 15 & 15 & 11 & 15 & 8 & 12 \\
\hline Spain (ES) & 24 & 24 & 24 & 24 & 24 & 23 & 22 & 20 & 20 \\
\hline Sweden (SE) & 1 & 1 & 4 & 4 & 4 & 4 & 1 & 1 & 7 \\
\hline United Kingdom (UK) & 14 & 14 & 14 & 14 & 14 & 16 & 9 & 23 & 19 \\
\hline
\end{tabular}

Source: own elaboration.

Table 3 presents the assessment of order compliance with selected methods measured by Kendall's rank correlation coefficient. 
Table 3. Values of the Kendall's rank correlation coefficients according to selected methods

\begin{tabular}{|c|l|l|l|l|l|l|l|l|l|}
\hline Method & $(1)$ & $(2)$ & $(3)$ & $(4)$ & $(5)$ & $(6)$ & $(7)$ & $(8)$ & $(9)$ \\
\hline$(1)$ & 1 & 1 & 0.952 & 0.952 & 0.952 & 0.783 & 0.693 & 0.714 & 0.677 \\
\hline$(2)$ & 1 & 1 & 0.952 & 0.952 & 0.952 & 0.783 & 0.693 & 0.714 & 0.677 \\
\hline$(3)$ & 0.952 & 0.952 & 1 & 1 & 1 & 0.831 & 0.688 & 0.73 & 0.725 \\
\hline$(4)$ & 0.952 & 0.952 & 1 & 1 & 1 & 0.831 & 0.688 & 0.73 & 0.725 \\
\hline$(6)$ & 0.952 & 0.952 & 1 & 1 & 1 & 0.831 & 0.688 & 0.73 & 0.725 \\
\hline$(7)$ & 0.783 & 0.783 & 0.831 & 0.831 & 0.831 & 1 & 0.614 & 0.868 & 0.788 \\
\hline$(8)$ & 0.693 & 0.693 & 0.688 & 0.688 & 0.688 & 0.614 & 1 & 0.577 & 0.603 \\
\hline$(9)$ & 0.714 & 0.714 & 0.73 & 0.73 & 0.73 & 0.868 & 0.577 & 1 & 0.772 \\
\hline
\end{tabular}

Source: own elaboration based on Table 2 .

The assessment of order compliance using various standardization methods, measured by Kendall's rank correlation coefficient, indicates the existence of significant relationships between the positions of countries. The strongest correlation was observed between the orders made using the following normative methods: (1) and (3), (4) and (5), as well as between (2) and (3).

Most often the best positions in the ordering of countries using different standardizing formulas were taken by: the Netherlands and Germany, and the worst - Greece and Cyprus.

To answer the question: "The results of which ordering should be considered optimal?" partial measures of correctness of the linear ordering procedures were calculated and an aggregate measure was determined on their basis, the values of which for individual methods are presented in Table 4.

Table 4. Values of the aggregate measure of correctness of procedures for linear ordering of EU countries in terms of socio-economic situation

\begin{tabular}{|c|c|}
\hline Method with normalization formula & The value of the measure of ordering correctness $M q$ \\
\hline$(1)$ & 72.262 \\
\hline$(2)$ & 9.004 \\
\hline$(3)$ & 9.155 \\
\hline$(4)$ & 2.406 \\
\hline$(5)$ & 9.159 \\
\hline$(6)$ & 9.196 \\
\hline$(7)$ & 1.121 \\
\hline$(8)$ & 0.830 \\
\hline$(9)$ & 4.139 \\
\hline
\end{tabular}

Source: own elaboration based on (Eurostat, 2017). 
In assessing the correctness of the linear ordering procedures, the criteria characterized in the section devoted to the research method were taken into account, i.e. mapping compatibility, linear and rank correlation of the synthetic variable with diagnostic variables, and variability of the synthetic variable.

Taking into account the results of all methods, the most optimal way of the linear ordering of objects is to order EU countries obtained by the method based on the normative transformation (8), i.e. using the quotient transformation with an arithmetic mean. Linear ordering with a quotient transformation with a minimum value of features turned out to be slightly worse. However, ordering based on the standardization of features (1) gave the worst results, taking into account the adopted criteria.

Sweden took first place in the ranking considered best and Cyprus came last. In the case of Sweden, the best position was achieved due to the low unemployment rate and the very low rate of deep material deprivation. In addition, the investment rate remained high and the current account balance of payments in \% of GDP was positive, at a fairly high level compared to other countries. Last place was taken by Cyprus, where the majority of diagnostic features are characterized by very unfavourable values, e.g. high unemployment rate, high value of the deep material deprivation rate, low primary energy acquisition per 1000 inhabitants from renewable energy sources and the negative balance of current account balance in \% of GDP.

\section{Conclusion}

The article presents the issue of choosing the optimal procedure for the linear ordering of objects. In the literature on the subject, one can find many works in which, despite the use of several methods, the study ends with the creation of object rankings. The quality assessment of the results of the linear ordering of objects is the final stage of construction of the synthetic variable and plays an important role, especially in a situation when several methods were used to order the objects linearly. Measures based on different properties of the synthetic variable can be used for selecting the optimal methods, including the link between diagnostic features and the aggregate variable. The paper presents the results of a comparative analysis including the results of linear arrangements obtained based on the selected standardization methods. Using the aggregate quality measure, the most correct, from the point of view of the adopted criteria, linear arrangement of objects was selected.

The study was conducted using the example of data concerning 28 European Union countries according to the level of socio-economic development in the context of sustainable development. The linear ordering of countries based on standardization transformation turned out to be the least correct procedure for the linear ordering of objects among the methods selected for the study, and the most correct - the linear ordering of countries using the quotient transformation with the arithmetic mean.

The final results of the linear organization of objects depend to a large extent on the set of diagnostic characteristics that characterize the phenomenon studied 
and may vary depending on the characteristics adopted. The proposed procedure for assessing the quality of the results of linear ordering of objects by different methods, whether at the stage of character standardization or aggregation, can be useful in finally choosing the method of the linear organization of objects.

\section{References}

Bąk, A. (2013). Metody porządkowania liniowego w polskiej taksonomii - pakiet PLLORD. Prace Naukowe Uniwersytetu Ekonomicznego we Wroctawiu, (278), 54-62.

Bąk, A. (2015). Zagadnienie wyboru optymalnej procedury porządkowania liniowego w pakiecie PLLORD. Prace Naukowe Uniwersytetu Ekonomicznego we Wrocławiu, (384), 33-41.

Bąk, A. (2017). Statystyczne metody doboru zmiennych w porządkowaniu liniowym. Prace Naukowe Uniwersytetu Ekonomicznego we Wrocławiu, (468), 29-37.

Bąk, A. (2018). Analiza porównawcza wybranych metod porządkowania liniowego. Prace Naukowe Uniwersytetu Ekonomicznego we Wrocławiu, (508), 19-28.

Eurostat. (2017). Database - Eurostat [online]. Retrieved from https://ec.europa.eu/eurostat/data/database

Grabiński, T., Wydymus, S., and Zeliaś, A. (1989). Metody taksonomii numerycznej w modelowaniu zjawisk społeczno-gospodarczych. Warszawa: Wydawnictwo Naukowe PWN.

Hellwig, Z. (1968). Zastosowanie metody taksonomicznej do typologicznego podziału krajów ze względu na poziom ich rozwoju oraz zasoby i strukturę wykwalifikowanych kadr. Przegląd Statystyczny, (4), 307-327.

Kukuła, K. (2000). Metoda unitaryzacji zerowanej. Warszawa: Wydawnictwo Naukowe PWN.

Sompolska-Rzechuła, A. (2018). Pomiar i cena jakości życia w ujęciu regionalnym. Szczecin: Wydawnictwo Uczelniane Zachodniopomorskiego Uniwersytetu Technologicznego.

Wysocki, F. (2010). Metody taksonomiczne w rozpoznawaniu typów ekonomicznych rolnictwa i obszarów wiejskich, Poznań: Wydawnictwo Uniwersytetu Przyrodniczego w Poznaniu.

\section{WYBÓR METODY PORZĄDKOWANIA LINIOWEGO NA PRZYKLADZIE OCENY POZIOMU ROZWOJU SPOŁECZNO-GOSPODARCZEGO KRAJÓW UNII EUROPEJSKIEJ}

Streszczenie: Celem artykułu jest przedstawienie zagadnienia wyboru optymalnej procedury liniowego uporządkowania obiektów i oceny poprawności wybranych metod liniowego uporządkowania obiektów. Cel został osiągnięty poprzez stworzenie liniowego uporządkowania obiektów przy użyciu różnych metod normalizacji wartości cech diagnostycznych. Do wyboru optymalnego uporządkowania zastosowano zmienną agregatową opartą na różnych jej właściwościach, m.in. na: zgodności odwzorowania, korelacji liniowej zmiennej syntetycznej ze zmiennymi diagnostycznymi, korelacji rangowej zmiennej syntetycznej ze zmiennymi diagnostycznymi oraz zmienności zmiennej syntetycznej. Badanie przeprowadzono na przykładzie danych dotyczących 28 krajów Unii Europejskiej ze względu na poziom rozwoju społeczno-gospodarczego w kontekście zrównoważonego rozwoju. Najbardziej prawidłowe okazało się uporządkowanie liniowe krajów z wykorzystaniem przekształcenia ilorazowego ze średnią arytmetyczną.

Słowa kluczowe: liniowe porządkowanie, optymalna procedura, normalizacja cech diagnostycznych. 